DOI: https://doi.org/10.32839/2304-5809/2021-7-95-27

УДК 336.717

Ушакова О.А.

Відокремлений структурний підрозділ «Рівненський технічний фаховий коледж Національного університету водного господарства та природокористування»

\title{
РОЗВИТОК ОПЕРАЦІЙ З ПЛАТІЖНИМИ КАРТКАМИ В БАНКАХ УКРАЇНИ
}

\begin{abstract}
Анотація. Статтю присвячено розвитку операцій з банківськими платіжними картками в Україні. З'ясовано поняття банківських карток як електронних платіжних засобів й зміст механізму безготівкових розрахунків за їх допомогою відповідно до вимог чинного законодавства. Описано етапи розвитку ринку платіжних карток в Україні. Проаналізовано стан ринку банківських платіжних карток в Україні. Виявлено, що показники розвитку ринку платіжних карток мають помітну тенденцію до зростання, і навіть невеликі банки розвивають карткові продукти. На прикладі АТ «ОКСІ БАНК» здійснено аналіз сегменту банку на ринку платіжних карток України і проаналізовано фрінансові результати та фрінансову безпеку операцій з ними. Запропоновано можливі заходи для підвищення конкурентної позиції банку і рівня доходів від карткового бізнесу.
\end{abstract}

Ключові слова: банківська платіжна картка, електронний платіжний засіб, безготівкові розрахунки, ринок платіжних карток, банк.

Ushakova Oksana

Separated structural subdivision 'Rivne Technical Professional College of the National University of Water and Environmental Engineering'

\section{DEVELOPMENT OF PAYMENT CARD TRANSACTIONS IN BANKS OF UKRAINE}

Summary. The article is devoted to the development of transactions with bank payment cards in Ukraine. The trend of active distribution of payment cards is significant as one of the priorities of monetary regulation of the economy by the National Bank of Ukraine. This is explained by the goals of solving the problems of cash turnover, which are achieved by increasing the efficiency of automated systems of non-cash payments. The concept of bank cards as electronic means of payment and the content of the mechanism of non-cash payments with their help have been clarified. The stages of development of the payment card market in Ukraine have been described. Its formation was changed both by stages of significant growth, which was accompanied by qualitative changes, and by periods of recession in the conditions of instability of the domestic economy. The state of the bank payment cards market in Ukraine have been analyzed. It was found that the indicators of the development of the payment card market tend to increase and even small banks develop card products. The analysis of the bank segment in the market of payment cards of Ukraine have been carried out and the financial results and security of operations with them have been analyzed on the example of OKCI BANK, JSC. The Bank actively implements modern technologies, in particular the mobile application 'Sportbank', which is promoted through digital marketing, partner networks, offline, referral program. The volume of settlement operations with the use of the bank's cards is growing and its work on securing financial risks is intensifying. At the same time, the bank is just beginning its entry into the Ukrainian payment card market. Possible measures to increase the bank's competitive position and the level of income from the card business have been proposed. These include: increasing the volume of payment cards; expanding the range of card products; use of credit cards in consumer lending; focus on retirees and students; development of service infrastructure; introduction of cash-back technology; development of direct sales; increasing the base of salary projects.

Keywords: bank payment card, electronic means of payment, non-cash payments, payment card market, bank.

$\Pi$ остановка проблеми. Банківська платіжна картка є спеціальним платіжним інструментом, держатель якого ініціює переказ грошей із відповідного рахунка платника або банку, а також здійснюе інші операції, передбачені договором [13]. Визначним досі залишається тренд щодо активного поширення платіжних карток на території України як один із пріоритетів грошово-кредитного регулювання економіки збоку Національного банку України (НБУ). Це пояснюеться цілями вирішення проблем готівкового обороту, які досягаються через підвищення ефективності роботи автоматизованих систем безготівкових розрахунків.

Аналіз останніх досліджень і публікацій. Проблеми розвитку ринків безготівкових розрахунків, платіжних карток, національної карткової платіжної системи, напрями використання платіжних карток, забезпечення банкіської безпеки держави при цьому в Україні досліджують Д.М. Гладких [2], М.О. Свдокімова [3], М.В. Луцик [8], Г.Л. Монастир- ський та Я.І. Чайковський [9], Ю.І. Онищенко [10], С.О. Пиріг, Л.І. Іщук та І.В. Олександренко [12], а також інші вітчизняні і зарубіжні вчені.

Виділення невирішених раніше частин загальної проблеми. Розрахунки з використанням готівки надзвичайно дорого обходяться як державі, так і комерційним фрінансовим структурам. Випуск в обіг нових купюр, обмін старих, утримання значного персоналу, незручності і великі втрати часу на рядових кліентів - усе це обтяжуе економіку країни. Тому актуальним $є$ дослідження місця розрахунків з використанням банківських платіжних карток в системі безготівкових розрахунків.

Мета статті - виявлення шляхів підвищення ефективності операцій банку з платіжними картками.

Виклад основного матеріалу. Законом України «Про платіжні системи та переказ грошей в Україні» № 2346-III від 05.04.2001 визначені загальні засади фуннкціонування платіжних 
систем в Україні, поняття і загалњний порядок про-ведення переказу грошей в межах України, а також відповідальність суб'єктів переказу. Основним елементом автоматичних платіжних систем є банківський автомат самообслуговування (банківський автомат) - програмно-технічний комплекс, що надає можливість держателю електронного платіжного засобу (ЕПЗ) здійснити самообслуговування за операціями одержання коштів у готів-ковій формі, внесення їх для зарахування на відповідні рахунки, одержання інформащії щодо стану рахунків, а також виконати інші операщії згідно 3 функціональними можливостями џьго комплексу. Суб'єктом відносин в автоматичних платіжних системах є держатель ЕПЗ - це фрізична особа, яка на законних підставах використовуе ЕПЗ для ініціювання переказу коштів з відповідного рахунку в банку або здійснюе інші операції із застосуванням зазначеного ЕПЗ. Спеціальний платіжний засіб (платіжна картка тощо) - це платіжний інструмент, що виконуе фрункцію засобу ідентифрікації, за допомогою якого держателем цього інструмента ініціюеться переказ грошей з відповідного рахунка платника або банку, а також здійснюються інші операщії, передбачені відповідним договором. За допомогою спеціальних платіжних засобів формуються документи за операціями із застосуванням спеціальних платіжних засобів або надаються інші послуги держателям спеціальних платіжних засобів. Платіжна система - це платіжна організація, члени платіжної системи та сукупність відносин, що виникають між ними при проведенні переказу грошей. Проведення переказу грошей є обов'язковою фрункцією, що має виконувати платіжна система. Роботу автоматичних платіжних систем забезпечують фінансові установи, які є особливими організаціями та виконують спеціальні операції [19].

Регулювання діяльності з випуску електронних грошей в Україні та запровадження моніторингу за такою діяльністю регламентується Положенням про електронні гроші в Україні № 25-212/1645-10454 від 30.07.2008. Положення визначає поняття випуску електронних грошей, держателя і користувача картки, емітента, обмінних операцій з електронними грошима, їх погашення та розповсюдження, системи електронних грошей тощо [14].

Механізм безготівкових розрахунків за допомогою платіжних карток в Україні обумовлений Постановою Правління НБУ «Про здійснення операцій з використанням електронних платіжних засобів» № 705 від 05.11.2014, яка регламентує емісію ЕПЗ, здійснення операцій з використанням ЕПЗ, особливості емісії мобільних платіжних інструментів і здійснення операцій з їх використанням, еквайрингу, загальні вимоги до безпеки здійснення платіжних операцій та управління ризиками, загальні правила документообігу за операціями з використанням ЕПЗ, агентську і посередницьку діяльність (аутсорсинг), процесинг, міжбанківські перекази за операціями з використанням ЕПЗ, моніторинг та контроль за операціями з їх використанням [17]. Це Положення розроблене згідно iз Законами України «Про НБУ» № 679-XIV від 20.05.1999 [18], «Про банки і банківську діяльність» № 2121-III від 07.12.2000 [16], «Про платіжні системи та переказ коштів в Україні» № 2346-III від 05.04.2001 [19], іншими законодавчими та нормативно-правовими актами України [4-6].
Етапи розвитку ринку платіжних карток в Україні беруть свій початок ще у фінансовобанківській системі СРСР: 1. 1969-1986 роки початок прийому платежів державним комітетом CPCP з іноземного туризму через ВАТ «Інтурист»; 2. 1987-1990 роки - еквайринг торгових підприемств по картках Visa та Europay госпрозрахунковим об'єднанням «Інтурсервіс»; 3. 1991-1995 роки - співробітництво 3 міжнародними платіжними системами на рівні агентських угод, створення власних платіжних систем українськими банками, створення міжбанківського ЗАТ «Укркарт»; 4. 1996 рік - теперішній час - участь у міжнародних платіжних системах, функціонування НПС України «Простір», інтенсивний розвиток ринку платіжних карток.

Його формування змінювалось як етапами значного зростання, яке супроводжувалося якісними змінами, так і періодами спаду в умовах нестабільності вітчизняної економіки. Сьогодні показники розвитку ринку платіжних карток мають помітну тенденщію до зростання.

В умовах пандемії COVID-19 безготівкові розрахунки 3 платіжними картками в Україні активно зростають. Загальна кількість операцій (безготівкових та з отримання готівки) 3 використанням платіжних карток, емітованих українськими банками, за 2020 рік становила 5997,1 млн шт., а їх сума 3957,3 млрд грн. Порівняно з 2019 роком кількість зазначених операцій зросла на $18,6 \%$, а сума - на 10,6\%. Водночас безготівкові операції з використанням платіжних карток стають все більш популярними серед українців. Так, за кількістю операцій торік переважали безготівкові - майже 87\% операцій 3 платіжними картками. Сума безготівкових операцій становила 55,8\% від усіх операщій із картками (за підсумками 2019 року - 50,3\%). Загалом, у 2020 рощі проти 2019 року кількість безготівкових операцій із використанням платіжних карток збільшилася на 25\% і становила 5211,2 млн шт., а сума - на майже $23 \%$ та досягла 2208,7 млрд грн. Як наслідок, кількість операщій отримання готівки у 2020 році знизилася на $11,7 \%$, а сума - на 1,7\%. Водночас у 2020 році українщі змінювали свої платіжні звички. Наприклад, середня сума операції переказу з картки на картку за рік зменшилася на 10,3\%, до 1444 грн; середня сума операщії в платіжних терміналах (pos-терміналах) - на 5\%, до 229 грн. Також середня сума операції в мережі Iнтернет зросла до 338 грн. Це свідчить, що українці все активніше здійснюють онлайн-платежі, зокрема й на більші суми. Сума операцій в мережі Інтернет зростала у 2020 році найбільшими темпами (відбулося зростання на 31\% порівняно із 2019 роком). Загалом кожна третя безготівкова операщія 3 платіжною карткою у 2020 році здійснювалася в мережі Інтернет $(36,5 \%)$. Це майже 642 млрд грн за 2020 рік. Половина всіх безготівкових операщій із використанням платіжних карток (49,8\%) здійснювалася в платіжних терміналах. Їх сума становила чверть від усіх безготівкових операщій (26,9\%). Якщо в 2019 році це було 513 млрд грн, то у 2020 році - 595 млрд грн (відбулося зростання на $16 \%$ порівняно із 2019 роком). У 2020 році найбільшу частку за сумою безготівкових операщій із використанням платіжних карток (як і в минулому та позаминулому роках) становили перекази 3 картки на картку (42,8\%), хоча за кількістю опера- 
цій їх частка - всього 12,6\%. За рік сума переказів 3 картки на картку зросла майже на чверть (24\%), до 945 млрд грн. Проте, це втричі менше, ніж було у минулому році (у 2019 році відбулось зростання на $64 \%$ у порівнянні із 2018 роком). За 2020 рік загальна кількість платіжних карток в Україні зросла на 8\%. Упродовж усього минулого року активно використовувалися безконтактні картки, смартфони й інші NFC-пристрої для здійснення безконтактних платежів. Іх популярність зумовлена високим рівнем безпеки, швидкістю і зручністю таких операцій. 57\% операцій за сумою і за кількістю здійснювалися в торговельних платіжних терміналах безконтактно. Незважаючи на карантинні обмеження, за 2020 рік платіжна інфраструктура суттево розширилася. Кількість суб'єктів господарювання, які приймають платіжні картки, за рік зросла більше ніж на $36,1 \%$. Мережа торговельних pos-терміналів за рік зросла на понад 12\%. Майже 87\% торговельних платіжних терміналів забезпечують можливість здійснення безконтактної оплати. Станом на 01.01.2021 в Україні зареєстровано 70 учасників карткових платіжних систем [11].

Таким чином, сьогодні спостерігається гостра конкуренція банків у всіх сегментах їх діяльності, в тому числі і на ринку платіжних карток, оскільки зростає кількість защікавлених клієнтів у надійному і зручному засобі розрахунку, що має стимулювати банківські установи до розвитку якісних послуг та продуктів. У таких умовах навіть невеликі банки намагаються заявити про себе і розробляють власні карткові продукти. Дослідимо можливості підвищення ефективності операцій з банківськими платіжними картками на прикладі одного з банків, які не мають лідуючих позицій на ринку платіжних карток України й у банківському сектоpi загалом, а саме: АТ «ОКСТ БАНК».

АТ «ОКСТ БАНК» створено у 2008 році. Головний офріс банку розташований у центрі Львова. Він $\epsilon$ універсальною фрінансово-кредитною установою, що обслуговуе суб'єктів господарської діяльності i фрізичних осіб. Банк є партнером АТ «Кредобанк». Банком-спонсором виступає АБ «Укргазбанк». Банк є членом Асощіації українських банків; має відлілення у Хмельницькому, Харкові, Киеві; є учасником Фонду гарантування вкладів орізичних осіб. Банк приеднаний до систем міжнародних грошових переказів Western Union, MoneyGramm, Аверс, Анелік тощо; підключений до міжнародної платіжно-інформаційної системи SWIFT і до інформаційної системи Reuters; є повноправним членом НПС «Простір» й оператора платіжних систем «УКрКарт» як емітент та еквайр [7; 15].

Процесинговий центр, який здійснюе процесинг карток «MasterCard®», емітованих AT «OКС БАНК», - ПАТ «УкрКарт». Працюе 9 банкоматів в різ-них містах, а саме: у Львові, Хмельницькому, Киеві, Харкові. Обслуговування в банкоматах систем АТ «Кредобанк» для клієнтів здійснюеться на пільгових умовах. Приймаються до обслуговування картки: MПC «Visa», MПC «Mastercard®», НПС «ПРОСТIР», кобейджингові картки ПС «ПРОСТIP-Union Pay», ПС «УКРКАРТ» [1; 7].

АТ «ОКСІ БАНК» є учасником Внутрішньодержавної платіжної системи “Сity24» згідно Договору № ПС-У-17/2019 від 18 липня 2019 року. Платіжна організація - ТОВ «ФК ФЕНІКС» (м. Київ). Виплата здійснюється в національній валюті.
У якості учасника внутрішньодержавної платіжної системи «Сity24» банк плануе здійснювати такі операції: поповнення мобільних телефонів за допомогою мобільного додатку «Sportbank»; проведення платежів на оплату комунальних послуг за допомогою мобільного додатку «Sportbank»; поповнення карток Sportbank за допомогою терміналів самообслуговування внутрішньодержавної платіжної системи «Сity24» [15].

Обсяг емісії міжнародних платіжних карток у 2019 році становив 2750 штук, в т.ч. видано 1672 штуки. На обслуговуванні є 35 діючих зарплатних проєктів (усього на обслуговуванні - 140). За 2020 рік банк прийняв на обслуговування 13 нових зарплатних проєктів (загальна кількість проєктів на обслуговуванні зменшилась до 136).

Банк активно впроваджуе сучасні технології. Орієнтується на інновації для того, щоб надавати кліентам максимально зручні сервіси і найбільш якісні продукти.

У 2019 році вдалося досягти значних звершень у побудові високотехно-логічного й інноваційного банкінгу. Банком здійснено значні інвестиції у впровадження нового продукту, що зорієнтований на фрізичних осіб - активних користувачів смартфонів. Реалізовано відкриття поточного рахунку для фрізичної особи 3 використанням ЕПЗ за допомогою мобільного додатку. Кліентам емітуються картки МПС «MasterCard». Реалізовані наступні шляхи для поповнення картки: за допомогою сервісу "перекидання 3 картки на картку", через міжбанківський платіж, через термінали самообслуговування банків-партнерів. На рахунок передбачено встановлення кредитного ліміту із пільговим періодом погашення до 120 днів. Особливістю продукту Sportbank є програма лояльності у вигляді 10\% «кешбеку» на послуги і товари в категорії «Спорт», в яку входять: магазини спортивних товарів, одягу та взуття, спортивні клуби, секції, студії танців, боулінг і більярд. У 2020 році розпочато розробку редеральної програми для залучення клієнтів і введення в дію продукту "Розстрочка» [20].

До 2022 року АТ «ОКСІ БАНК» продовжуватиме реалізацію проєкту із впровадження продукту Sportbank. За даними фрінансової звітності банку [20] динаміка його результатів за 2017-2019 роки демонструе значне падіння прибутку у 2018 році до - 2517 тис. грн з 475 тис. грн у 2017 році і відновлення прибутковості у 2019 році на рівні 6987 тис. грн, що свідчить про позитивні наслідки капітальних вкладень у впровадження продукту «Sportbank».

Основна ціль проєкту для банку - збільшити частку i продовжити розвиток роздрібного напрямку за допомогою формату «мобільного банку", який дає ряд конкурентних переваг перед стандартними продуктами інших банків: завдяки розвитку мобільного Інтернету та досягненню частки використання смартфронів 85\% від загальної кількості цифрових пристроїв такий фрормат надає можливість суттево економити на витратах 3 утримання персоналу i розширити географію кліентів до всеукраїнської; дистанційне підписання договорів з банком з використанням електронних цифррових підписів; наповнення додатку програмою лояльності, різноманітними видами шаблонних платежів мотивуе клієнта використовувати карту Sportbank як основну. Просування 
продукту Sportbank на ринку передбачає використання декількох основних каналів залучення клієнтів: циоровий маркетинг (генерація клієнтів від СРА-мереж, просування в сощіальних мережах, реклама в Google Ads i в маркетах, SEO просування сайту; робота з лідерами думок (інтеграція з блогерами), ролики на Youtube тощо); партнерські мережі - співробітництво з офлайнпартнерами в частині проведення спільних заходів із залучення клієнтів в мережі магазинів/ клубів, а також відкриття в магазинах партнерів офрлайн-місць видачі карт Sportbank; офрлайнпросування - участь у якості спонсора, або в якості учасника в спортивних заходах, які проходять в Україні, в тому числі за підтримки партнера Mastercard, офрлайн-реклама (борди тощо); pedpeральна програма для клієнтів [20].

У рамках реалізації проєкту передбачено діяльність контактного центру, який дає можливість в режимі 24/7 надавати підтримку клієнтам по продукту «Sportbank» 3 використанням теледронії і месенджерів типу Viber, Telegram та Facebook Messenger. Серед пріоритетних завдань 3 автоматизації внутрішніх процесів - забезпечення надійного електронного внутрішнього документообігу банку i документообігу при обслуговуванні клієнтів, удосконалення системи управління інформаційною безпекою та управління технологічним ризиком.

Відносно овердрафртів і кредитних карт для фрізичних осіб та поновлюваних механізмів кредитування для юридичних осіб, які включають кредит i незатребуваний компонент прийнятого зобов'язання, банк може оцінювати кредитні збитки у періоді, що перевищує максимальний період за договором, якщо передбачено можливість вимагати погашення кредиту та анулювати незатребуваний компонент прийнятого зобов'язання, яка не обмежує існування кредитних ризиків строком для подачі повідомлення про припинення (табл. 1).

Аналіз демонструе фракт появи дебіторської заборгованості за кредитними операціями, але суттєвого зменшення дебіторської заборгованості за переказами фрізичних осіб (практично на 95\%) і зменшення нарахованих доходів (інших та розрахунково-касового обслуговування) практично на $31 \%$. Грошові ж

кошти з обмеженим правом використання зросли на практично на 189\%. Така ситуація свідчить про те, що за овердрафртами і кредитними картами для фрізичних осіб погіршились показники погашення кредитних лімітів, що й призвело до необхідності збільшення резерву під знецінення інших фінансових активів практично на $52 \%$.

У таблиці 2 за 2019 та 2018 роки відображено майнові права, надані у забезпечення фрінансової безпеки при проведенні розрахунків по операціях, що здійснюються 3 використанням платіжних карток, емітованих АТ «ОКСІ БАНК».

Спостерігається відсутність коштів, наданих у забезпечення фрінансової безпеки при проведенні розрахунків по операщіях, що здійснюються з використанням карток, емітованих АТ «ОКСІ БАНК», і відсутність забезпечених зобов'язань. Майнові ж права зросли практично на 189\%. Це свідчить про зростання обсягів розрахункових операцій з використанням карток банку й активізацію його роботи з убезпечення фрінансових ризиків.

Таким чином, упровадження інновацій, дистанційних каналів обслуговування клієнтів, надання широкого спектра карткових продуктів є пріоритетними напрямками розвитку для AT «ОКСI БАНК». Банк намагаеться розширювати спектр послуг і продуктів та проводить постійну роботу для підвищення якості обслуговування держателів карток. Разом 3 тим, слід відзначити, що банк не відіграє значної ролі на ринку платіжних карток України як за обсягом випуску, так і за обладнанням, що їх обслуговує, адже без розгалуженої сітки банкоматів, відділень та терміналів самообслуговування неможливо збільшити кількість активних користувачів картками. Крім того, важливу роль в активізації операцій банків з платіжними картками відіграють зарплатні проєкти, проте АТ «ОКСІ-БАНК» не можна назвати лідером у цьому контексті.

3 огляду на результати аналізу сегменту ринку платіжних карток, на якому працюе банк, можемо констатувати той фракт, що запровадження нових карткових продуктів і програм, спрямованих на залучення клієнтів АТ «ОКСІ БАНК» не $є$ активним. Банк лише розпочинає своє входження на цей ринок.

Таблиця 1

Динаміка грошових коштів з обмеженим правом використання, наданих у забезпечення фінансової безпеки при проведенні розрахунків по операціях, що здійснюються з використанням платіжних карток, емітованих АТ «ОКСІ БАНК» у 2018-2019 роках

\begin{tabular}{|l|c|c|c|c|}
\hline \multicolumn{1}{|c|}{ Найменування статті } & $\mathbf{3 1 . 1 2 . 2 0 1 9}$ & $\mathbf{3 1 . 1 2 . 2 0 1 8}$ & $\begin{array}{c}\text { Абсолютне } \\
\text { відхилення, } \\
\text { тис. грн }\end{array}$ & $\begin{array}{c}\text { Відносне } \\
\text { відхилення, \% }\end{array}$ \\
\hline $\begin{array}{l}\text { Дебіторська заборгованість } \\
\text { за кредитними операціями }\end{array}$ & 156 & - & 156 & - \\
\hline $\begin{array}{l}\text { Дебіторська заборгованість } \\
\text { за переказами фізичних осіб }\end{array}$ & 5 & 102 & -97 & $-95,10$ \\
\hline $\begin{array}{l}\text { Нараховані доходи (інші та } \\
\text { розрахунково-касове обслуговування) }\end{array}$ & 34 & 49 & -15 & $-30,61$ \\
\hline $\begin{array}{l}\text { Грошові кошти з обмеженим правом } \\
\text { використання }\end{array}$ & 1827 & 633 & 1194 & 188,63 \\
\hline $\begin{array}{l}\text { Резерв під знецінення } \\
\text { інших фрінансових активів }\end{array}$ & $(238)$ & $(157)$ & 81 & 51,59 \\
\hline $\begin{array}{l}\text { Усього інших фінансових активів } \\
\text { за мінусом резервів }\end{array}$ & 1784 & 627 & 1157 & 184,53 \\
\hline
\end{tabular}

Джерело: проаналізовано автором за даними [20] 
Динаміка активів, що надані в заставу без припинення визнання АТ «ОКСІ БАНК» у 2018-2019 роках

\begin{tabular}{|c|c|c|c|c|c|c|}
\hline \multirow[b]{2}{*}{$\begin{array}{c}\text { Найменування } \\
\text { статті }\end{array}$} & \multicolumn{2}{|c|}{31.12 .2019} & \multicolumn{2}{|c|}{31.12 .2018} & \multirow[b]{2}{*}{$\begin{array}{c}\text { Абсолютне } \\
\text { відхилення, } \\
\text { тис. грн }\end{array}$} & \multirow[b]{2}{*}{$\begin{array}{c}\text { Відносне } \\
\text { відхилення, } \\
\%\end{array}$} \\
\hline & $\begin{array}{c}\text { Активи, } \\
\text { надані } \\
\text { в заставу }\end{array}$ & $\begin{array}{l}\text { Забезпечене } \\
\text { зобов'язання }\end{array}$ & $\begin{array}{c}\text { Активи, } \\
\text { надані } \\
\text { в заставу }\end{array}$ & $\begin{array}{l}\text { Забезпечене } \\
\text { зобов'язання }\end{array}$ & & \\
\hline Майнові права & 1827 & - & 633 & - & 1194 & 188,63 \\
\hline Усього & 1827 & - & 633 & - & 1194 & 188,63 \\
\hline
\end{tabular}

Джерело: проаналізовано автором за даними [20]

3 нашої точки зору, для підвищення конкурентної позиції і рівня доходів від карткового бізнесу АТ «ОКСІ БАНК» та банків з подібною позицією на ринку платіжних карток доцільно: нарощувати обсяги емісії платіжних карток; розширювати асортимент карткових продуктів; ширше застосовувати кредитні картки у споживчому кредитуванні - надання кредиту на споживчі потреби на картковий рахунок кліента; діяти на ринку платіжних карток для пенсіонерів та студентів, зокрема орієнтуючись на кредитування осіб пенсійного віку; розвивати інфраструктуру обслуговування (збільшення мережі банкоматів, POS-терміналів тощо); упроваджувати технологію cash-back - повернення невеликих сум готівки власникові картки в магазинах; розвивати прямі продажі карткових продуктів («мобільні банкіри»); нарощувати базу зарплатних проектів.
Висновки і пропозиціі. Отже, саме за допомогою карток кліенти можуть отримувати заробітну плату і пенсію, розраховуватися в торговельних мережах, замовляти та оплачувати найрізноманітніші послуги, здійснювати банківські перекази й одержувати кредити, в тому числі за допомогою безконтактних платежів та розрахунків в Інтернеті. Платіжні банківські карти відрізняються привабливими тарифами, оперативним оформленням, забезпечують безготівкове перерахування коштів на картковий рахунок з будь-якого українського й закордонного банку та цілодобовий доступ до коштів на картковому рахунку. Таким чином, розвиток показників ринку платіжних карток в Україні нестримно змінюеться і виклик часу спонукає до необхідності глибшого погляду практичних сторін організації, позиціонування і розвитку карткової справи в банках.

\section{Список літератури:}

1. Банкомати. Офіційний сайт AT «ОКСI БАНК». URL: https://www.okcibank.com.ua/privatnim-klientam/ bankomati (дата звернення: 12.03.2021)

2. Гладких Д. М. Банківська безпека держави в умовах розвитку інформаційної економіки (трансформації банківських операцій) : монографія. Київ : НУОУ, 2019. 393 с.

3. Свдокімова М. О. Особливості фрунціонування та проблемні питання розвитку платіжної системи України. Науковий погляд: еконоліка та управління. 2020. № 3(69). С. 97-102.

4. Інструкція про безготівкові розрахунки в Україні в національній валюті : Постанова Правління НБУ № 22 від 21.01.2004. URL: https://zakon.rada.gov.ua/laws/show/z0377-04№Text (дата звернення: 05.02.2021).

5. Інструкція про ведення касових операцій банками в Україні : Постанова Правління НБУ № 103 від 25.09.2018. URL: https://zakon.rada.gov.ua/laws/show/v0103500-18№Text (дата звернення: 05.02.2021).

6. Інструкція про порядок відкриття, використання і закриття рахунків у національній та іноземних валютах: Постанова Правління НБУ № 492 від 12.11.2003. URL: https://zakon.rada.gov.ua/laws/show/z1172-03№Text (дата звернення: 05.02.2021).

7. Консолідована фінансова звітність Банківської Групи, відповідальною особою якої е АТ «КРЕДОБАНК», та звіт незалежного аудитора 31 грудня 2020 року. URL: https://kredobank.com.ua/public/upload/680f979b82151 e89416002741a2d0eb5.pdf (дата звернення: 12.03.2021).

8. Луцик М. В. Аналіз ринку безготівкових розрахунків. Науковий вісник Міжнародного гуланітарного університету. 2020. Вип. 42. С. 171-177.

9. Монастирський Г. Л., Чайковський Я. І., Чайковська І. Я., Чайковський Є. Я. Напрями використання платіжних карток як інноващії оплати послуг транспортних організащій. Еконолічний аналіз. 2018. Том 28. № 4. С. $143-154$.

10. Онищенко Ю. І. Оцінка рівня розвитку ринку платіжних карток в Україні. Інфбраструктура ринку. 2017. Вип. 7. С. 345-351. URL: http://www.market-infr.od.ua/journals/2017/7_2017_ukr/60.pdf

11. Основні тренди карткового ринку у 2020 році: безконтактні платежі та розрахунки в Інтернеті. URL: https://bank.gov.ua/ua/news/all/osnovni-trendi-kartkovogo-rinku-u-2020-rotsi-bezkontaktni-plateji-tarozrahunki-v-interneti (дата звернення: 05.02.2021).

12. Пиріг С. О., Іщук Л. І., Олександренко І. В. Оцінка рівня ринку платіжних карток та чинники впливу на його розвиток. Еконолічний фборул. 2021. № 1. С. 184-192.

13. Платіжні картки. Офіційний сайт АТ «ОКСI БАНК». URL: https://www.okcibank.com.ua/privatnim-klientam/ platizhni-kartki (дата звернення: 12.03.2021).

14. Положення про електронні гроші в Україні № 25-212/1645-10454 від 30.07.2008 року. URL: https:/zakon.rada.gov.ua/ laws/show/v1045500-08№Text (дата звернення: 05.02.2021).

15. Про банк. Офіційний сайт АТ «ОКСI БАНК». URL: https://www.okcibank.com.ua/pro-bank (дата звернення: 12.03.2021).

16. Про банки і банківську діяльність : Закон України № 2121-III від 07.12.2000. URL: https://zakon.rada.gov.ua/ laws/show/2121-14№Text (дата звернення: 05.02.2021).

17. Про здійснення операщій з використанням електронних платіжних засобів : Постанова Правління НБУ № 705 від 05.11.2014. URL: https://zakon.rada.gov.ua/laws/show/v0705500-14№Text (дата звернення: 05.02.2021).

18. Про НБУ : Закон України № 679-XIV від 20.05.1999. URL: https://zakon.rada.gov.ua/laws/show/679-14№Text (дата звернення: 05.02.2021). 
19. Про платіжні системи та переказ коштів в Україні : Закон України № 2346-III від 05.04.2001. URL: https:// zakon.rada.gov.ua/laws/show/2346-14№Text (дата звернення: 05.02.2021).

20. Фінансова звітність АТ «ОКСІ БАНК» за рік, що закінчився 31 грудня 2019 року. Разом із Аудиторським висновком (Звітом незалежного аудитора). Офіційний сайт AT «OКСI БАНК». URL: https://www.okcibank.com.ua/ uploads/files/zvit/rik/annual_report-2019.pdf (дата звернення: 12.03.2021).

\section{References:}

1. OKCI BANK, JSC. Bankomaty [ATMs]. Available at: https://www.okcibank.com.ua/privatnim-klientam/ bankomati (accessed 12 March 2021).

2. Hladkykh D. M. (2019) Bankivska bezpeka derzhavy v umovakh rozvytku informacijnoyi ekonomiky (transformaciyi bankivskykh operacij): monohrafiia [Banking security of the state in the conditions of information economy development (transformation of banking operations): monograph]. Kyiv: NUOU. (in Ukrainian)

3. Yevdokimova M. O. (2020) Osoblyvosti funkcionuvannya ta problemni pytannya rozvytku platizhnoyi systemy Ukrayiny [Features of functioning and problematic issues of development of the payment system of Ukraine]. Scientific View: Economics and Management, no. 3(69), pp. 97-102.

4. Board of the National Bank of Ukraine (2004) Instrukciya pro bezgotivkovi rozrakhunky v Ukrayini v nacionalnij valyuti. Postanova № 22 vid 21.01.2004 [Instruction on non-cash payments in Ukraine in national currency. Resolution No 22 of January 21, 2004]. Available at: https://zakon.rada.gov.ua/laws/show/z0377-04№Text (accessed 05 February 2021).

5. Board of the National Bank of Ukraine (2018) Instrukcziya pro vedennya kasovykh operacij bankamy v Ukrayini. Postanova № 103 vid 25.09.2018 [Instruction on conducting cash operations by banks in Ukraine. Resolution No 103 of September 25, 2018]. Available at: https://zakon.rada.gov.ua/laws/show/v0103500-18№Text (accessed 05 February 2021).

6. Board of the National Bank of Ukraine (2003) Instrukciya pro poryadok vidkryttya, vykorystannya i zakryttya rakhunkiv u nacionalnij ta inozemnykh valyutakh: Postanova № 492 vid 12.11.2003 [Instruction on the procedure for opening, using and closing accounts in national and foreign currencies. Resolution No 492 of December 11, 2003]. Available at: https://zakon.rada.gov.ua/laws/show/z1172-03№Text (accessed 05 February 2021).

7. KREDOBANK, JSC (2020) Konsolidovana finansova zvitnist Bankivskoyi Grupy, vidpovidalnoyu osoboyu yakoyi ye AT «KREDOBANK», ta zvit nezalezhnogo audytora 31 grudnya 2020 roku [Consolidated financial statements of the Banking Group, the responsible person of which is KREDOBANK, JSC, and the report of the independent auditor on December 31, 2020]. Available at: https://kredobank.com.ua/public/upload/680f979b82151e89416002741a2d0eb5.pdf (accessed 12 March 2021).

8. Lutsyk M. V. (2020) Analiz rynku bezgotivkovykh rozrakhunkiv [Analysis of the non-cash payments market]. Scientific Bulletin of the International Humanities University, vol. 42, pp. 171-177.

9. Monastyrskyi H. L., Chaikovskyi Ya. I., Chaikovska I. Ya., Chaikovskyi Ye. Ya. (2018) Napryamy vykorystannya platizhnykh kartok yak innovaciyi oplaty poslug transportnykh organizacij [Directions of using payment cards as innovations of payment for services of transport organizations]. Economic Analysis, vol. 28, no. 4, pp. $143-154$.

10. Onyshchenko Yu. I. (2017) Ocinka rivnya rozvytku rynku platizhnykh kartok v Ukrayini [Assessment of the level of development of the payment card market in Ukraine]. Infrastruktura rynku [Market Infrastructure] (electronic journal), vol. 7, pp. 345-351. Available at: http://www.market-infr.od.ua/journals/2017/7_2017_ukr/60.pdf (accessed 09 July 2021).

11. The National Bank of Ukraine (2020) Osnovni trendy kartkovogo rynku u 2020 roci: bezkontaktni platezhi ta rozrakhunky $\mathrm{v}$ Interneti [The main trends of the card market in 2020: contactless payments and payments on the Internet]. Available at: https://bank.gov.ua/ua/news/all/osnovni-trendi-kartkovogo-rinku-u-2020-rotsibezkontaktni-plateji-ta-rozrahunki-v-interneti (accessed 05 February 2021).

12. Pyrih S. O., Ishchuk L. I., Oleksandrenko I. V. (2021) Ocinka rivnya rynku platizhnykh kartok ta chynnyky vplyvu na jogo rozvytok [Assessment of the level of the payment card market and factors influencing its development]. Economic Forum, no. 1, pp. 184-192.

13. OKCI BANK, JSC. Platizhni kartky [Payment cards]. Available at: https://www.okcibank.com.ua/privatnimklientam/platizhni-kartki (accessed 12 March 2021).

14. Board of the National Bank of Ukraine (2008) Polozhennya pro elektronni groshi v Ukrayini № 25-212/1645-10454 vid 30.07.2008 roku [Regulation on electronic money in Ukraine No 25-212/1645-10454 of July 30, 2008]. Available at: https://zakon.rada.gov.ua/laws/show/v1045500-08№Text (accessed 05 February 2021).

15. OKCI BANK, JSC. Pro bank [About the bank]. Available at: https://www.okcibank.com.ua/pro-bank (accessed 12 March 2021).

16. Verkhovna Rada of Ukraine (2000) Pro banky i bankivsku diyalnist: Zakon Ukrayiny № 2121-III vid 07.12.2000 [About banks and banking. Law of Ukraine No 2121-III of December 7, 2000]. Available at: https://zakon.rada.gov.ua/laws/show/2121-14№Text (accessed 05 February 2021).

17. Board of the National Bank of Ukraine (2014) Pro zdijsnennya operacij z vykorystannyam elektronnykh platizhnykh zasobiv: Postanova № 705 vid 05.11.2014 [About carrying out operations with use of electronic means of payment. Resolution No 705 of November 5, 2014]. Available at: https://zakon.rada.gov.ua/laws/show/ v0705500-14№Text (accessed 05 February 2021).

18. Verkhovna Rada of Ukraine (1999) Pro Nacionalnyj bank Ukrayiny: Zakon Ukrayiny № 679-XIV vid 20.05.1999 [About the National Bank of Ukraine. Law of Ukraine No 679-XIV of May 05, 1999]. Available at: https://zakon.rada.gov.ua/laws/show/679-14№Text (accessed 05 February 2021).

19. Verkhovna Rada of Ukraine (2001) Pro platizhni systemy ta perekaz koshtiv v Ukrayini: Zakon Ukrayiny № 2346-III vid 05.04.2001 [About payment systems and funds transfer in Ukraine. Law of Ukraine No 2346-III of April 5, 2001]. Available at: https://zakon.rada.gov.ua/laws/show/2346-14№Text (accessed 05 February 2021).

20. OKCI BANK, JSC (2019) Finansova zvitnist AT «OKSI BANK» za rik, shho zakinchyvsya 31 grudnya 2019 roku. Razom iz Audytorskym vysnovkom (Zvitom nezalezhnogo audytora) [Financial statements of OKCI BANK, JSC for the year ended December 31, 2019. Together with the Auditor's Report (Independent Auditor's Report)]. Available at: https://www.okcibank.com.ua/uploads/files/zvit/rik/annual_report-2019.pdf (accessed 12 March 2021). 